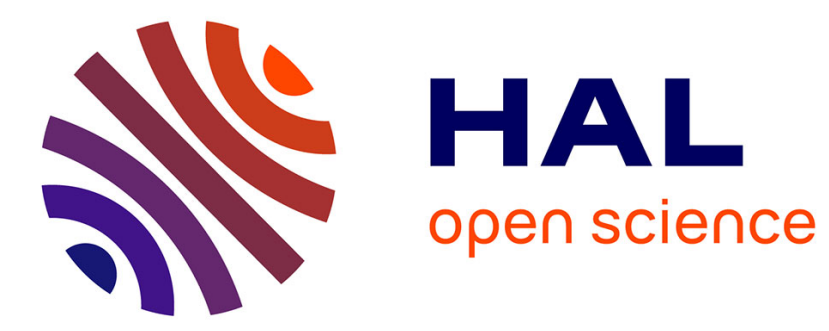

\title{
Low-temperature amino-based catalyst activation for on-demand polyurethane synthesis
}

Romain Lambert, Emmanuel Ibarboure, Guillaume Fleury, Stéphane Carlotti

\section{To cite this version:}

Romain Lambert, Emmanuel Ibarboure, Guillaume Fleury, Stéphane Carlotti. Low-temperature amino-based catalyst activation for on-demand polyurethane synthesis. Polymer Journal, 2020, 52 (1), pp.45-49. 10.1038/s41428-019-0246-8 . hal-02431122

\section{HAL Id: hal-02431122 \\ https://hal.science/hal-02431122}

Submitted on 2 Jul 2020

HAL is a multi-disciplinary open access archive for the deposit and dissemination of scientific research documents, whether they are published or not. The documents may come from teaching and research institutions in France or abroad, or from public or private research centers.
L'archive ouverte pluridisciplinaire HAL, est destinée au dépôt et à la diffusion de documents scientifiques de niveau recherche, publiés ou non, émanant des établissements d'enseignement et de recherche français ou étrangers, des laboratoires publics ou privés. 


\title{
Low temperature amino-based catalyst activation for on-demand polyurethane synthesis
}

\author{
Romain Lambert, Emmanuel Ibarboure, Guillaume Fleury, Stéphane Carlotti* \\ Univ. Bordeaux, CNRS, Bordeaux INP, LCPO, UMR 5629, F-33600, Pessac, France \\ E-mail: carlotti@enscbp.fr
}

\section{Running head}

Thermo-latent catalyst for the "on-demand" PU synthesis

\section{Keywords}

Polyurethane, latent catalyst, activation, organic catalyst

\begin{abstract}
A new latent catalyst, based on 1,5-diazabicyclo[4.3.0]non-5-ene (DBN), has been specifically designed to be thermally deprotected at low temperature. More generally, specific isocyanurates based on the reaction of two substituted isocyanates and DBN are used as precatalyst for polyurethane synthesis. The activation temperature of the pre-catalysts is determined by DSC and resulting free catalysts activity is demonstrated through a catalysis cycle on a PU model reaction.
\end{abstract}

\section{Introduction}

For almost a century, the synthesis of polyurethane never stops to be studied and their field of application continues to widen., ${ }^{1,2}$ Discovered by Bayer and co-workers in $1937,{ }^{3}$ the reaction 
between a diisocyanate and a diol (typically a polyester diol) catalyzed by a metal/amine couple allows to design polymers ranging from thermoplastics with tailored mechanical properties to functional foams thanks to the multitude of available substituents. ${ }^{4,5}$ The main advantage of the use of isocyanates is their high reactivity even at low temperatures or in highly viscous systems, ensuring a rapid conversion. ${ }^{6}$ For some industrial application, this high reactivity can also be a major drawback since specific applications need latency in order to allow delivery and shaping of the mixture into a mold or template. In this perspective, some strategies appear in the literature based on blocked isocyanate, ${ }^{7}$ or on catalyst modification ${ }^{8}$ with the aim to design a stimuli-responsive mixture able to switch on the polymerization by simple external request. In an industrial context, the catalyst modification appears as the most promising strategy because the lower quantity used and, de facto, the lower cost involved.

A strategy described by Landais and coworkers consists in the use of two equivalents of monoisocyanate to mask the aminated co-catalyst through the formation of an isocyanurate derivative. ${ }^{9}$ They observed cleavage temperature from $69^{\circ} \mathrm{C}$ to $176^{\circ} \mathrm{C}$ depending on amine and isocyanate nature and from $72^{\circ} \mathrm{C}$ to $162^{\circ} \mathrm{C}$ only focusing on the 1,5diazabicyclo[4.3.0]non-5-ene (DBN) amine.

Based on this approach we performed polyurethane (PU) synthesis by working with selected functionalized isocyanate in order to decrease the cleavage temperature. In this perspective, amine has been fixed on DBN ${ }^{10,11}$ and electronically attractive groups are added to isocyanate structure in order to decrease the strength of the C-N bonds of isocyanurate moieties (Figure 1, 4a-c). In addition to the simplest aromatic isocyanate, two chemical groups such as nitro and fluoride were selected because of their $-\mathrm{M}$ effect and high intrinsic electronegativity, respectively (Figure 1, compounds 1-3). 

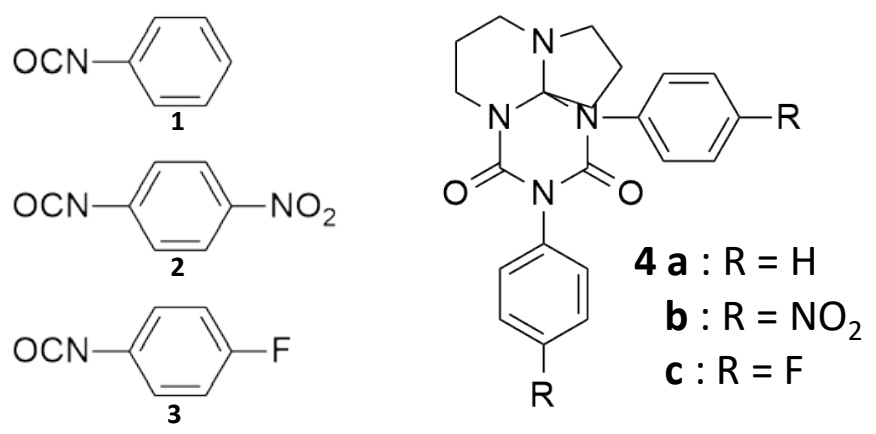

Figure 1: Isocyanates used (1-3) for the synthesis of isocyanurate derivative precatalysts (4a-c)

\section{Experimental}

\section{Materials}

Isocyanates including phenylisocyanate (99\%, Acros Organics), 4-nitrophenylisocyanate (97\%, Sigma Aldrich) and 4-fluoroisocyanate (99\% Acros Organics), were used directly as received. 1,5-Diazabicyclo[4.3.0]non-5-ene (98\%, DBN) was used as received from ABCR. Toluene was received from Sigma Aldrich, dried under polystyryllithium seeds and distilled prior to use. Hydroxy-telechelic polybutadiene (HTPB) and 4,4-dicyclohexylmethane diisocyanate (MDCI, 90\%) were purchased from Sigma Aldrich and used directly as received.

\section{Instruments}

NMR: ${ }^{1} \mathrm{H}$ NMR spectra were recorded on a Bruker AC-400 spectrometer in appropriate deuterated solvents. All ${ }^{13} \mathrm{C}$ measurements were performed at $298 \mathrm{~K}$ on a Bruker Avance III 400 spectrometer operating at $100.7 \mathrm{MHz}$. To describe the multiplicities of the signals, the following abbreviations were used: s: singlet, bs: broad signal, d: doublet, t: triplet, q: quartet, m: multiplet.

DSC: Differential scanning calorimetry analyses (DSC) were carried out on a DSC Q100 LN2 TA Instrument. The DBN derivatives $(10 \mathrm{mg})$ were heated from $-50{ }^{\circ} \mathrm{C}$ to $150^{\circ} \mathrm{C}$ at a rate of $10{ }^{\circ} \mathrm{C} \cdot \mathrm{min}^{-1}$. The instrument was calibrated with indium sample. 
FT-IR: Fourier transform infrared spectra were recorded using a Bruker FT-IR spectrometer (Vertex 70) in transmission mode using ATR equipment. All spectra were recorded between 400 to $4000 \mathrm{~cm}^{-1}$, with a resolution of $4 \mathrm{~cm}^{-1}$ and 64 scans. To compare samples, the same baseline correction was used and the spectra were normalized to the signal at $2930 \mathrm{~cm}^{-1}$, which was not affected by the chemical modifications. The isocyanate band at $2280 \mathrm{~cm}^{-1}$ was selected to determine the conversion. The calculation of conversion is obtained as follow: $t_{0}$ is admitted as $0 \%$ conversion and the baseline as $100 \%$ conversion. The ratio of the peaks area leads to the conversion for each sample.

Synthesis of precatalyst 4a-c: A solution of $15 \mathrm{mmol}$ of DBN in $15 \mathrm{~mL}$ of dry diethyl ether was added drop-wise to an ethanol-cooled solution $\left(-30^{\circ} \mathrm{C}\right)$ of $30 \mathrm{mmol}$ of the selected isocyanate in $40 \mathrm{~mL}$ dry toluene. The solution was stirred for $24 \mathrm{~h}$ at room temperature. After removing the solvent at $25^{\circ} \mathrm{C}$ under vacuum for $12 \mathrm{~h}$, targeted products $4 \mathrm{a}$, $4 \mathrm{~b}$ and $4 \mathrm{c}$ were obtained in yields ranging from 76 to $84 \%$ and stored at $4^{\circ} \mathrm{C}$.

NMR (CDCl 3,3 ppm): 4a, ${ }^{1} \mathrm{H}: 7.2-7.4$ (m, Ar, 10H), 4.3 and 3.1 (dd, N-CH $\left.2,2 x 1 \mathrm{H}\right), 2.9$ and 2.3 (dd, N-CH2, 2x1H), 2.7 (m, - $\left.\mathrm{CH}_{2^{-}}, 4 \mathrm{H}\right), 2.9$ (m, - $\left.\mathrm{CH}_{2^{-}}, 2 \mathrm{H}\right), 2.9$ and 2.3 (dd, $\left.-\mathrm{CH}_{2}, 2 \mathrm{x} 1 \mathrm{H}\right)$. ${ }^{13} \mathrm{C}: 151,152,147,148,128-130$ (Ar), 92, 50.5, 48.5, 47.5, 34, 19.8, 21.5. 4b, ${ }^{1} \mathrm{H}:$ 7.1-7.3 (m, Ar, 4H), 4.3 and 3.1 (dd, N-CH, $2 x 1 \mathrm{H}$ ), 2.9 and 2.3 (dd, N-CH2, 2x1H), $2.7\left(\mathrm{~m},-\mathrm{CH}_{2^{-}}, 4 \mathrm{H}\right), 2.9$ (m, - $\left.\mathrm{CH}_{2-}, 2 \mathrm{H}\right), 2.6$ and $2.3\left(\mathrm{dd},-\mathrm{CH}_{2}, 2 \mathrm{x} 1 \mathrm{H}\right) .{ }^{13} \mathrm{C}: 151,152,147$, 148, 128-130 (Ar), 92, 50.5, 48.5, 47.5, 34, 19.8, 21.5.

4c, ${ }^{1} \mathrm{H}: 6.9-7.3$ (m, Ar, 4H), 4.3 and 3.1 (dd, N-CH2, 2x1H), 3.0 and 2.5 (dd, N-CH2, 2x1H), $2.8\left(\mathrm{~m},-\mathrm{CH}_{2-}, 4 \mathrm{H}\right), 2.9\left(\mathrm{~m},-\mathrm{CH}_{2^{-}}, 2 \mathrm{H}\right), 2.7$ and $2.5\left(\mathrm{dd},-\mathrm{CH}_{2}, 2 \mathrm{x} 1 \mathrm{H}\right) .{ }^{13} \mathrm{C}: 151,152,147$, 148, 128-130 (Ar), 92, 50.5, 48.5, 47.5, 34, 19.8, 21.5.

PU synthesis example: HTPB (10g) was put in a glass flask containing magnetic bar and was dried $1 \mathrm{~h}$ at $70^{\circ} \mathrm{C}$ under high vacuum. MDCI $(1,17 \mathrm{~g})$ was then added and stirred for $10 \mathrm{~min}$. 
DBTL $(0.1 \%)$ and catalyst $4 \mathrm{~b}(0.5 \%)$ were then added and the mixture stirred at $20^{\circ} \mathrm{C}$ for $1 \mathrm{~h}$ and then $6 \mathrm{~h}$ at $60^{\circ} \mathrm{C}$. Kinetic profile was followed by FT-IR analysis.

\section{Results and discussion}

The reaction of isocyanates with DBN proceeds immediately by the formation of a 2:1 adduct at room temperature (see experimental section). As the reaction is fast and exothermic, the pre-catalyst synthesis was carried out at low temperature to avoid side-reaction or premature cleavage reaction. The adducts were obtained with high yields around $80 \%$ and directly used without any purification step. The mechanism of this reaction was first described by Richter et al. and is illustrated in Scheme 1.12,13

They suggested a two steps addition with the formation of zwitterionic intermediate. The first step consists in an addition of the DBN on the carbon of the isocyanate function of the first phenyl isocyanate moiety. The resulting zwitterionic intermediate is then added to a second phenyl isocyanate entity in order to form a second zwitterionic species. By an intramolecular cyclisation the anionic nitrogen is bonded to the sp2 carbon of DBN to form the neutral isocyanurate moiety. This mechanism also illustrates the impossibility to directly use diisocyanate as masking agent as intermolecular side-reactions could not be avoided. 


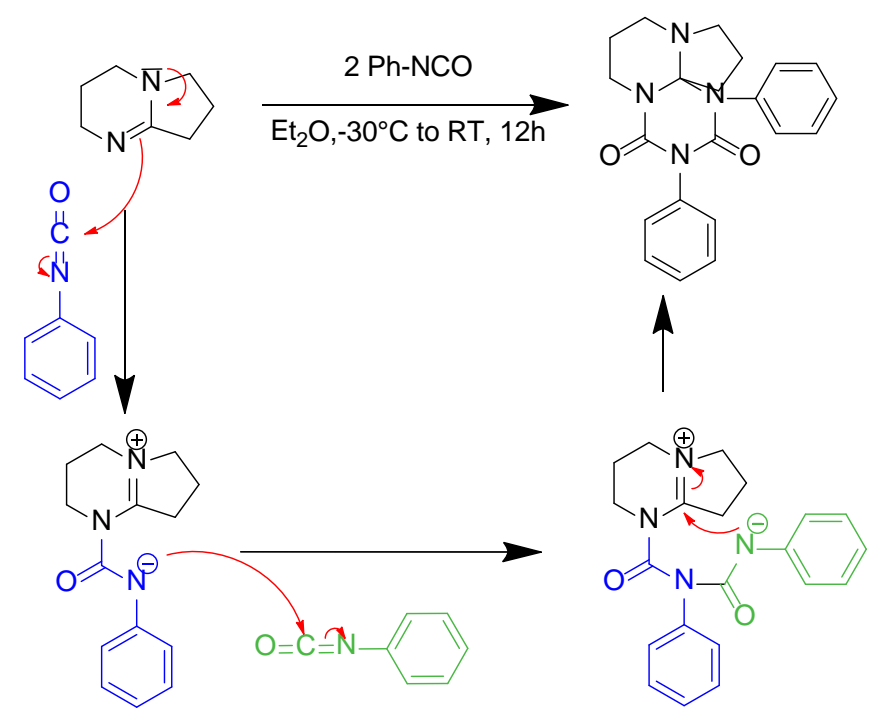

Scheme 1: Proposed mechanism for the formation of the 2:1 adduct between DBN and isocyanate moieties. $^{12,13}$

Pre-catalysts were fully characterized by ${ }^{1} \mathrm{H}$ and ${ }^{13} \mathrm{C}$ NMR on which all expected chemical shifts could be observed. Indeed, aromatics from isocyanate appears from 7 to $7.4 \mathrm{ppm}$ on ${ }^{1} \mathrm{H}$ NMR spectrum and from 128 to $140 \mathrm{ppm}$ on ${ }^{13} \mathrm{C}$ NMR spectrum in the same way that carbons characteristics to the $\mathrm{C}=\mathrm{O}$ functions of the isocyanurate are identified around $152 \mathrm{ppm}$ (Figure 2).

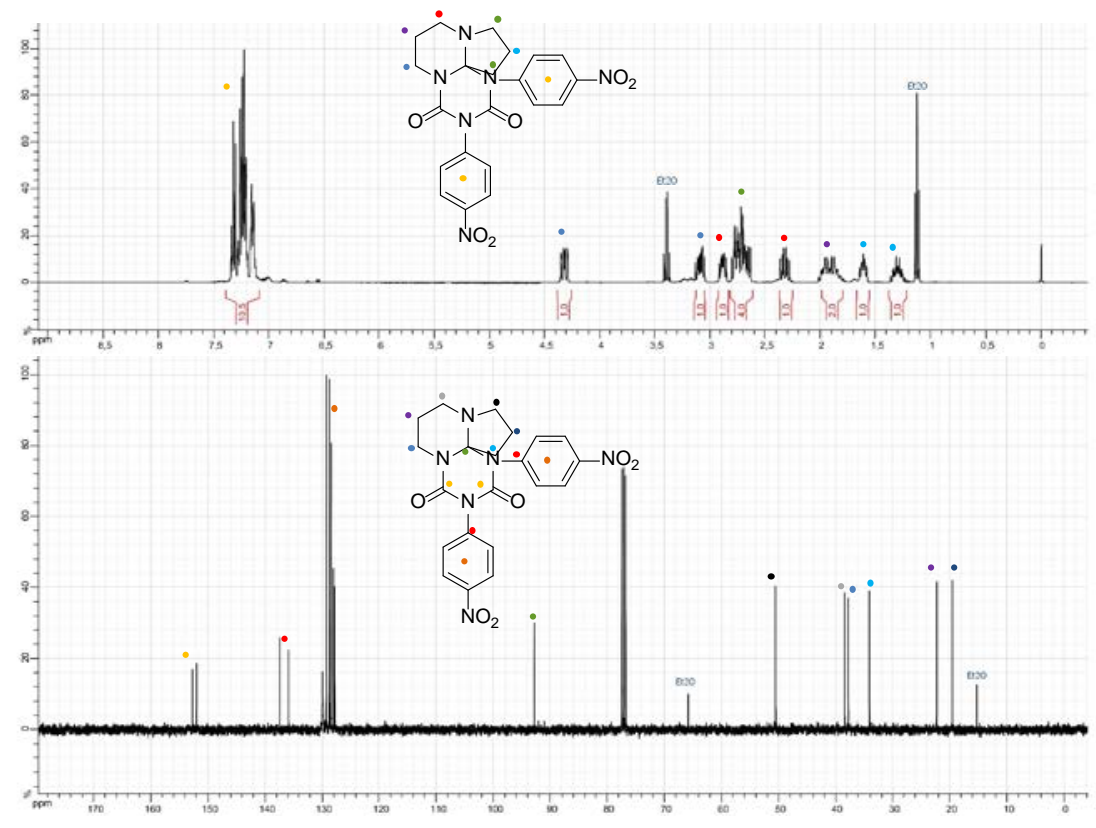

Figure 2: ${ }^{1} \mathrm{H}$ and ${ }^{13} \mathrm{C}$ NMR spectra of $\mathbf{4 b}$ performed in $\mathrm{CDCl}_{3}$ 
The cleavage temperature was then probed by differential scanning calorimetry analyses (Figure 3). The thermograms presented are therefore enlarged to the endothermic peak region. Thermograms of $4 \mathrm{a}-\mathrm{c}$ showed peaks ranging from 60 to $90^{\circ} \mathrm{C}$ for pre-catalyst $4 \mathrm{a}, 10^{\circ} \mathrm{C}$ to $80^{\circ} \mathrm{C}$ for $4 \mathrm{~b}$, and 80 to $115^{\circ} \mathrm{C}$ for $4 \mathrm{c}$. The optimums of these curves were considered as the cleavage temperature and were determined at $85^{\circ} \mathrm{C}$ for $4 \mathrm{a}, 46^{\circ} \mathrm{C}$ for $4 \mathrm{~b}$ and $112^{\circ} \mathrm{C}$ for $4 \mathrm{c}$, knowing that cleavage can occur below those temperatures.

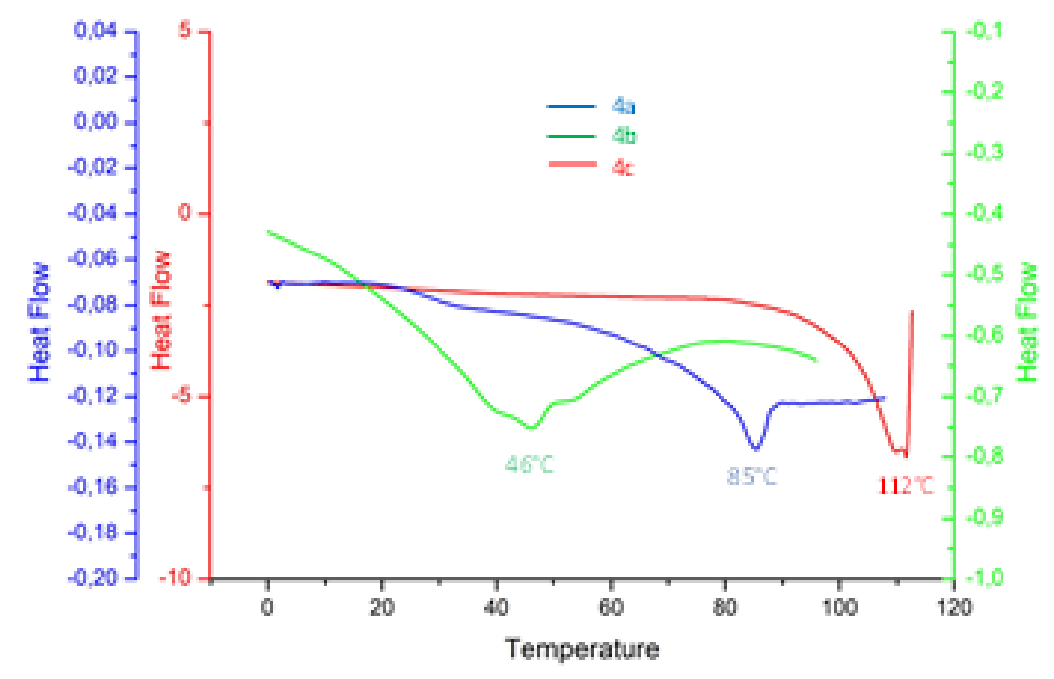

Figure 3: DSC curves (enlargement on the endothermic signal) of 4a (blue), 4b (green) and 4c red)

The range of cleavage temperature is in good agreement with the electronic effects induced by the chemical substituents in para of the isocyanate function with respectively $-\mathrm{H}$, $-\mathrm{NO} 2$. Concerning the fluoride substituent, the expected -I inductive effect has been outperformed by the $+\mathrm{M}$ mesomeric effect, leading to the higher cleavage temperature observed in this study. ${ }^{14}$ Thereby, the nitro group -which combined both inductive and mesomeric effects is the most efficient to decrease the cleavage temperature.

To illustrate the applicability of such an efficient system, pre-catalyst $4 \mathrm{~b}$-the most effectivewas used to catalyse the polymerization of HTPB and MDCI (Figure 4a). In line with 
industrial processes bulk reaction using a small amount of tin derivative (0.1\%o of DBTL) was used. A low amount of latent aminated pre-catalyst (0.5\%) was then added. The reaction was monitored using IR spectroscopy, regarding the disappearance of the signal of the isocyanate bond at $2280 \mathrm{~cm}^{-1}$ (Figure 4b). The reaction was first stirred at $20^{\circ} \mathrm{C}$ for 1 hour using $4 \mathrm{~b}$ (grey line) to show its low catalytic activity in its masked form since only $5 \%$ of conversion was reached and as compared with the $40 \%$ conversion obtained with free DBN (yellow line) at the same temperature (Figure 4c). The mixture was then placed at $60^{\circ} \mathrm{C}$ in order to deprotect the aminated co-catalyst. A significant increase of the kinetic was observed since the conversion increased from 5 to $54 \%$ in the following hour, attesting the release of free DBN in the mixture. As a point of comparison, catalyst $4 \mathrm{~b}$ in its masked form could only yield to low conversion (10\%) after 5h (grey line), demonstrating again its poor activity. Conversely, free $\mathrm{DBN}$ (orange and red lines) exhibits a high reactivity at $20^{\circ} \mathrm{C}$ and even more at $60^{\circ} \mathrm{C}$. The conversion vs time profile of $4 \mathrm{~b}$ after $1 \mathrm{~h}$ (blue line) is quite similar to the free DBN one at the same temperature $\left(60^{\circ} \mathrm{C}\right)$.

a)

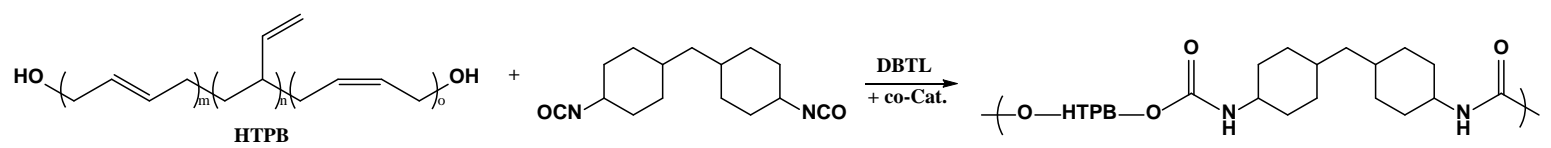

b)

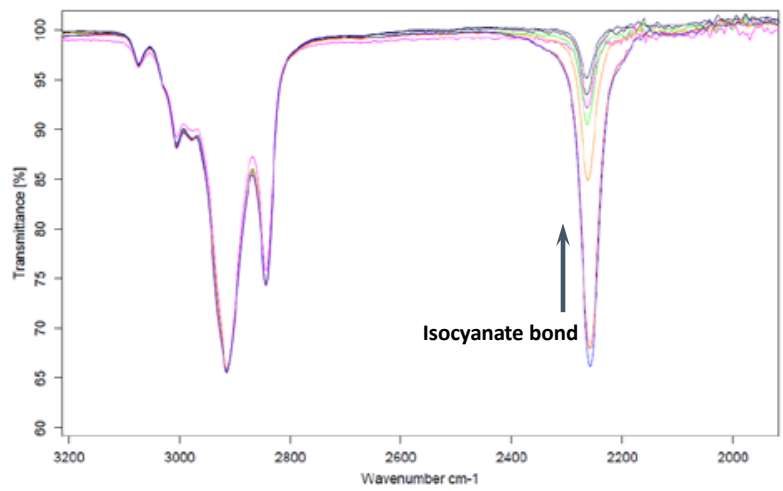

c)

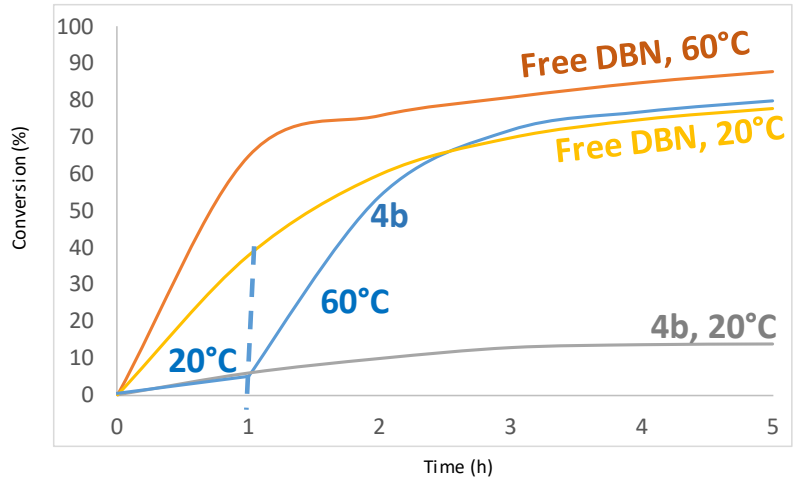

Figure 4: (a) Reaction studied (PU synthesis), (b) conversion measurement by FT-IR analysis and (c) conversion vs time profile of the HTPB/MDCI reaction performed using DBTL, for all systems, and unprotected co-catalyst (free $\mathrm{DBN}$ ) at $60^{\circ} \mathrm{C}$ (orange) and $20^{\circ} \mathrm{C}$ (yellow), 4b co-catalyst at $20^{\circ} \mathrm{C}$ and

$60^{\circ} \mathrm{C}$ after $1 \mathrm{~h}$ (blue) and $4 \mathrm{~b}$ at $20^{\circ} \mathrm{C}$ (grey). 


\section{Conclusions}

New thermo-latent catalysts are used for the "on-demand” synthesis of polyurethanes. These compounds are easily prepared from DBN and two equivalents of substituted isocyanates. After storage at low temperature, they appear very efficient when reaching a certain temperature. The nitrophenyl-based isocyanurate co-catalyst was exhibiting the lower cleavage temperature starting at about $10^{\circ} \mathrm{C}$. The thermo-latent characteristic was demonstrated through model reaction between HTPB and MDCI at $60^{\circ} \mathrm{C}$ by a poor catalytic activity of the masked catalyst at $20^{\circ} \mathrm{C}$ as compared to DBN-free system, and a high activity at $60^{\circ} \mathrm{C}$.

\section{References}

1. E. Delebecq, J.-P. Pascault, B. Boutevin, F. Ganachaud, Chem. Rev. 2012, 113, 1, 80.

2. H. Sardon, A. Pascual, D. Mecerreyes, D. Taton, H. Cramail, J. L. Hedrick, Macromol. 2015, 48, 10, 3153.

3. O. Bayer, Angew. Chem., 1947, 59, 257.

4. M. Szycher, Handbook of polyurethanes, CRC Press, Boca Raton, FL, 1999.

5. J. O. Akindoyo, M. D. H. Beg, S. Ghazali, M. R. Islam, N. Jeyaratnam, A. R. Yuvaraj, RSC Advances, $2016,6,114453$.

6. A. L. Silva, J. C. Bordado, Catalysis Reviews, 2004, 46, 31.

7. M. S. Rolph, A. L. J. Markowska, C. N. Warriner, R. K. O'Reilly, Polym. Chem., 2016,7, 7351.

8. A. L. Silva, J. C. Bordado, 2004, Catalysis Reviews, 46, 31.

9. J. Alsarraf, F. Robert, H. Cramail, Y. Landais, Polym. Chem., 2013, 4, 904.

10. I. Polenz, A. Laue, T. Uhrin, T. Rüffer, H. Lang, F. G. Schmidt, S. Spange, Polym. Chem., 2014, 5, 6678.

11. J. Alsarraf, Y. A. Ammar, F. Robert, E. Cloutet, H. Cramail, Y. Landais, Macromol., 2012, 45, 2249.

12. H. Ulrich, B. Tucker, A. A. R. Sayigh, Angew. Chem., Int. Ed. Engl., 1968, 7, 291.

13. R. Richter, Tetrahedron Lett., 1968, 48, 5037.

14. D. G. Streets, Chem. Phys. Lett, 1974, 28, 555.

\section{Figure Legends}

Scheme 1: Proposed mechanism for the formation of the 2:1 adduct between DBN and isocyanate moieties. $^{12,13}$

Figure 1: Isocyanates used (1-3) for the synthesis of isocyanurate derivative precatalysts (4a-c)

Figure 2: ${ }^{1} \mathrm{H}$ and ${ }^{13} \mathrm{C}$ NMR spectra of $\mathbf{4 b}$ performed in $\mathrm{CDCl}_{3}$

Figure 3: DSC curves (endothermic signal) of 4a (blue), 4b (green) and 4c red) 
Figure 4: (a) Reaction studied (PU synthesis), (b) conversion measurement by FT-IR analysis and (c) conversion vs time profile of the HTPB/MDCI reaction performed using DBTL, for all systems, and unprotected co-catalyst (free $\mathrm{DBN}$ ) at $60^{\circ} \mathrm{C}$ (orange) and $20^{\circ} \mathrm{C}$ (yellow), $4 \mathrm{~b}$ co-catalyst at $20^{\circ} \mathrm{C}$ and $60^{\circ} \mathrm{C}$ after $1 \mathrm{~h}$ (blue) and $4 \mathrm{~b}$ at $20^{\circ} \mathrm{C}$ (grey).

\section{Graphical Abstract}

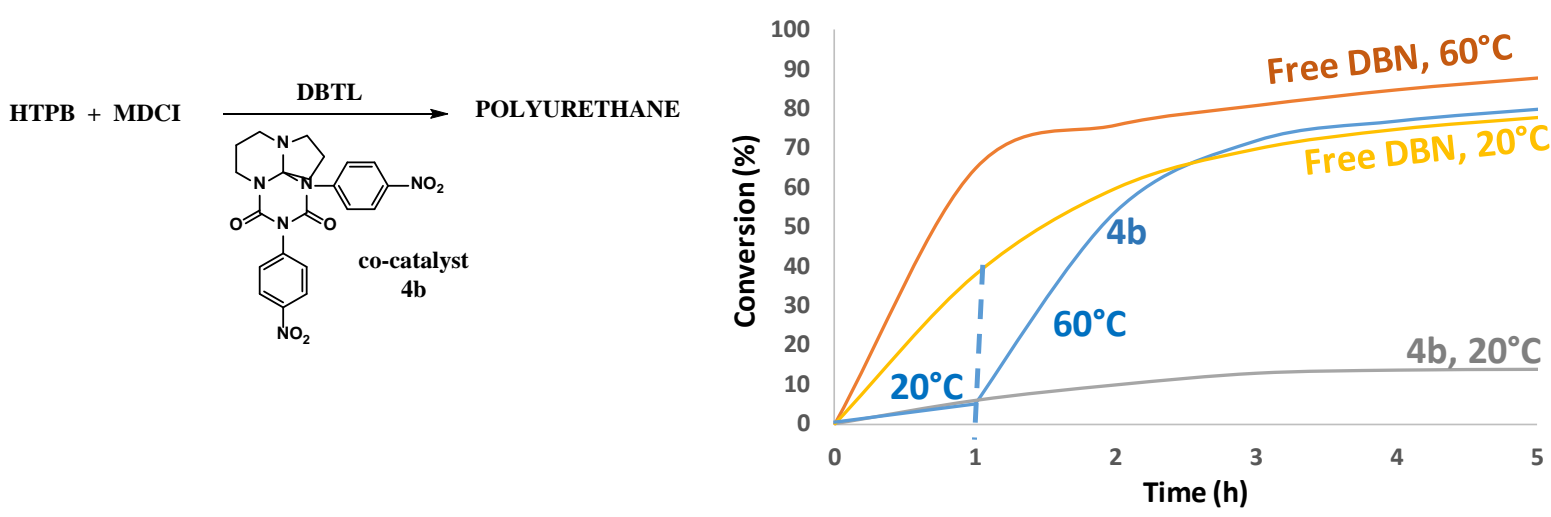

